\title{
İncir Ağaçlarının (Ficus carica L.) Yapraklarından Elde Edilen Bitki Çayının Bazı Özelliklerinin Araştırılması
}

\author{
Nergiz YÜKSEL*, Erdinç VURAL, Mustafa SÜRMEN \\ Aydın Adnan Menderes Üniversitesi, Germencik Yamantürk Meslek Yüksekokulu \\ (ORCID: 0000-0002-1334-051X) (ORCID: 0000-0002-3398-5593) (ORCID: 0000-0001-9748-618X)
}

\begin{abstract}
$\ddot{\mathbf{O z}}$
İncir (Ficus carica L.)yaprakları çok çeşitli biyolojik aktivitelere sahip olduğundan özellikle sağlık alanında çalışanların dikkatini çekmektedir. Bu çalışmanın amacı; Germencik yöresinden toplanan örneklerde Ficus carica L. yaprak çayının bazı fiziksel, kimyasal, morfolojik ve toksikolojik etkilerinin araştıılması; aynı zamanda yapılan analiz sonuçlarına göre incir yaprak çayının, ulusal bitki çayı standardına göre değerlendirilmesidir. Araştırmada toplanan örnekler çay haline getirilerek toplam kuru madde, toplam kül, asitte çözünmeyen kül, mezofilik aerobik bakteri, koliform bakteri, Escherichia coli, Salmonella spp. ve küf tayinleri yapılmıştır. Yapılan analiz sonuçlarına göre incelenen bu özelliklerden elde edilen veriler sirasıyla $\% 90,6(\mathrm{~m} / \mathrm{m}), \% 14,19(\mathrm{~m} / \mathrm{m}), \% 4,36(\mathrm{~m} / \mathrm{m}), 8,10^{*} 10^{1}$ $(\mathrm{kob} / \mathrm{g})<10(\mathrm{kob} / \mathrm{g}),<10(\mathrm{kob} / \mathrm{g})$ ve $2 * 10^{2}(\mathrm{kob} / \mathrm{g})$ olarak belirlenmiştir. Örneklerde aflatoksin ve boyar madde tespit edilmemiştir. Analiz sonuçları, toplam kül ve asitte çözünmeyen kül tayinleri dışında TS 12933 (ICS 67.140.10) numaralı Türk Standartları Enstitüsünün Bitkisel Çaylar Standardına uygun bulunmuştur. Çalışmamız bu kapsamda yapılan ilk araştırmadır. Birçok faydası bulunan incir yaprak çayının kimyasal ve toksikolojik özellikleri üzerine çalışmaların devam ettirilmesi ve incirin en çok üretildiği Aydın ilinde yan ürün olarak değerlendirilmesi gerektiği düşünülmektedir.
\end{abstract}

Anahtar kelimeler: Aydın, Ficus carica, İncir yaprak çayı, bitki çayı.

\section{Investigation of Some Properties of Plant Tea from Leaves of Fig Trees (Ficus carica L.)}

\begin{abstract}
Since the leaves of Ficus carica L. have a wide variety of biological activities, they have attracted the attention of healthcare workers in particular. The aim of this study; Investigation of some physical, chemical, morphological and toxicological effects of Ficus carica L. leaf tea in samples collected from Germencik region; at the same time according to the results of the analysis of fig leaf tea, according to the national herbal tea standard is to evaluate. The collected samples were made into tea by total dry matter, total ash, acid insoluble ash, mesophilic aerobic bacteria, coliform bacteria, Escherichia coli, Salmonella spp. and mold were determined. According to the results of the analysis, the data obtained from these properties were determined as $90,6 \%(\mathrm{~m} / \mathrm{m}), 14,19 \%(\mathrm{~m} / \mathrm{m}), 4,36 \%$ $(\mathrm{m} / \mathrm{m}), 8,10 * 101(\mathrm{cfu} / \mathrm{g})<10(\mathrm{cfu} / \mathrm{g}),<10(\mathrm{cfu} / \mathrm{g})$ ve $2 * 102(\mathrm{cfu} / \mathrm{g})$ respectively. Aflatoxin and dye were not detected. The results of the analysis were in compliance with TS 12933 (ICS 67.140.10) Herbal Tea Standard of Turkish Standards Institute, except for total ash and acid insoluble ash determinations. This is the first study in this context. It is thought that the studies on the chemical and toxicological properties of the fig leaf tea, which has many benefits, should be continued and evaluated as a by-product in the province of Aydın where the fig is produced most.
\end{abstract}

Keywords: Aydın, Ficus carica, tea of fig leaves, herbal tea.

\section{Giriş}

Moraceae, yenilebilir türler bakımından çok zengin bir kapalı tohum bitki ailesidir. Yaklaşık 750 türüyle monotipiktir. 37 cinsi olan Moraceae familyasının, Ficus cinsi 100'den fazla türden oluşur. İncir ticari

\footnotetext{
"Sorumlu yazar: nergiz.yuksel@adu.edu.tr

Geliş Tarihi: 10.12.2019, Kabul Tarihi: 09.04.2020
} 
öneme sahip en çok bilinen türüdür [1]. Moraceae (Mulberry) familyasına ait çok yıllık bitki türü olan incir ağaçları (Ficus carica L.) Dünyada en fazla Türkiye, A.B.D., Yunanistan ve İspanya'da yetişmektedir [2]. Bu bitkinin yetiştiği bölgelerin iklimi özellikle kışları 1lıman, yazları kurak geçmektedir [3]. Birleşmişmiş Milletler Tarım ve Gıda Örgütü (FAO) verilerinin son beş yıllık ortalama değerlerine göre Türkiye, yaklaşı 300 bin ton üretim ile Dünyadaki yaş incir üretiminin \%26,7'sini karşılayarak ilk sırada yer almaktadır. Ülke genelinde ise \%60,65 oran ile Aydın ili ilk sıradadır [4]. Aydın ilinde kuru incir rekolte tahmin tablosuna göre en çok incir yetişen ilçe ise Germencik'tir [5]. Yüksek güvenlik profiline sahip incirler, en eski gıdalardan biridir. F. carica L.'nın sadece meyvesi değil yaprakları, latexleri gıda olarak ve tedavi amacıyla kullanılmaktadır [1]. Özellikle gelişmekte olan ülkelerde, geleneksel hastalıkları tedavi etmek için ilaçlarla beraber kullanılmaktadır [6]. F. carica L., İspanyol ve İngiliz farmokolojisinde bitkisel ilaçların terapotik klavuzlarına dahil edilmiştir [1]. Brezilya halk tıbbında, Ficus adhatodifolia schott expreng ve Ficus obtusiuscula yapraklarından hazırlanan çaylar bulunmaktadır. Bu türlerin ikisi de Pharmacosycea alt cinsine aittir [7]. Lianju vd., (2003) incir meyve çayının içerisine direkt incir yapraklarının ilave edildiğini bildirmiştir [8]. İncir ve çeşitli kısımları ile ilgili yapılan çalışmalarda; incir ağacı yaprağından bazı flavonoidler, steroller ve aldehit, alkol, keton, ester, monoterpen, seskiterpen ve norizoprenoidler grubuna ait uçucu bileşikler izole edilmiştir $[9,10]$.

Pakistan'da yapılan bir çalışmada, küçük incir yapraklarında, p-hidroksibenzoik asit, sinapik asit glukozit, gallik asit türevi, kafeik asit türevi, kumarik asit türevi, kafeik asit, pro-antosinidin B1, katarik asit, kumaroil-heksoz, quercetin-3,7-diglukozit, quercetin-3-triglukozit, kikorik asit, quercetin3-glukozit ve kaempferol-3-O- soporotriozit olmak üzere 14 adet polifenolik bileşik tespit edilmiştir. Ayrıca çalışmada, yaprakların 45-60 günlük olgunlaşma döneminde daha zengin polifenolik bileşik kaynağı olduğu belirtilmiştir [3]. Diğer bir çalışmada ise incir ağacı yapraklarında potasyum, kalsiyum, magnezyum, sodyum, demir, fosfor, bakır, mangan ve çinko konsantrasyonlarının büyüme mevsimi boyunca bulunduğu belirtilmiştir [11]. Ficus carica L. türünde, toplam fenolik ve flavonoid içeriği belirlenerek; yaprak ekstraktlarında antioksidan ve antimikrobiyal aktivitelerinin değerlendirildiği bir çalışmada, incir ağacı yapraklarının antioksidan kapasitesi fenolik içerikle uyumlu bulunmuştur. Ayrıca tüm ekstreler Bacillus cereus ve Staphylococcus aureus'a karş1 antibmikrobiyal bir etki göstermiştir [12]. S. aureus ve E. coli gibi patojenik bakterilere karş1, incir yapraklarının antimikrobiyal aktivitesinin belirlendiği bir çalışmada; patojenik bakterilere karşı en yüksek \% 47 civarında verim gözlendiğinden dolayı incir bitkisinin alternatif antibiyotik geliştirme potansiyeli olduğu bildirilmiştir [13]. 2009 yılında yapılan bir çalışmada ise Ficus carica L. yapraklarının oral bakterilere karşı antimikrobiyal aktivitesi araştırılmış ve ağız bakım ürünlerinde doğan bir antimikrobiyal madde olarak kullanılabileceği bildirilmiştir [14].

Günümüze kadar, F. carica yapraklarının faydaları ile ilgili sağlık alanında birçok çalışma yapılmıştır. Kapsamlı bir çalışmada; kansızlık, diyabet, karaciğer hastalıkları, cilt hastalıkları, felç, kanser ve ülser tedavisinde $F$. carica' nın kullanıldığı bildirilmiştir [15]. F. carica'nın çeşitli kısımlarının antioksidan, antidiyabetik ve anti obesegonik etkilerinin araştırıldığ bir çalışmada ise, bu etkilere karşı potansiyel bir kaynak olduğu belirtilmiştir. $F$. carica yaprak dekoksiyonları, tip 1 diyabetik hastalarda hipoglisemik etki gösterdiği ve bergaplen ve prosalen adlı iki önemli anti kanser bileşiği içerdiği yapılan çalışmalarda bildirilmiştir [16]. Ayrıca, F. carica özlerinin ve bileşenlerinin meme kanseri hücreleri üzerinde spesifik büyüme önleyici etkilere sahip olduğu belirtilmiştir [17]. Hipoglisemik etki üzerine yapılan diğer bir çalışmada ise; $F$. carica yapraklarının kaynă̆ından elde edilen bir kloroform özütü kullanılarak sıçanların kolestrol seviyeleri düşürülmüştür [18]. Tıp alanında birçok uzman bilim insanı son yıllarda $F$. carica'ya yönelmiştir. Çünkü kimyası, besin değeri, farmakolojik kullanımları araştırılan F. carica'nın umut verici biyo ürünlerden biri olduğu düşünülmektedir [1]. Bu çalışmanın amacı, kimyası ve sağlık üzerine faydaları araştırılan $F$. carica yapraklarından elde edilen bitki çayının bazı özelliklerinin incelenmesidir. Ülkemizde uygulanan mevzuat ve Türk Standartları kapsamında yapılan analizler ile $F$. carica yapraklarından elde edilen bitki çayı değerlendirilmiştir. Ayrıca çalışmamız; $F$. carica L. yapraklarından üretilen çayın beslenme kalitesini belirlemeye yardımcı olacaktır. 


\section{Materyal ve Metot}

\subsection{Materyal}

İncir ağacının yaprakları çoğunlukla 5 lobludur, dalgalı ve kenarlıdır (Şekil 1). Araştırmada materyal olarak Germencik yöresinde yetiştirilen incir ağaçlarından toplanan yapraklar kullanılmıştır.

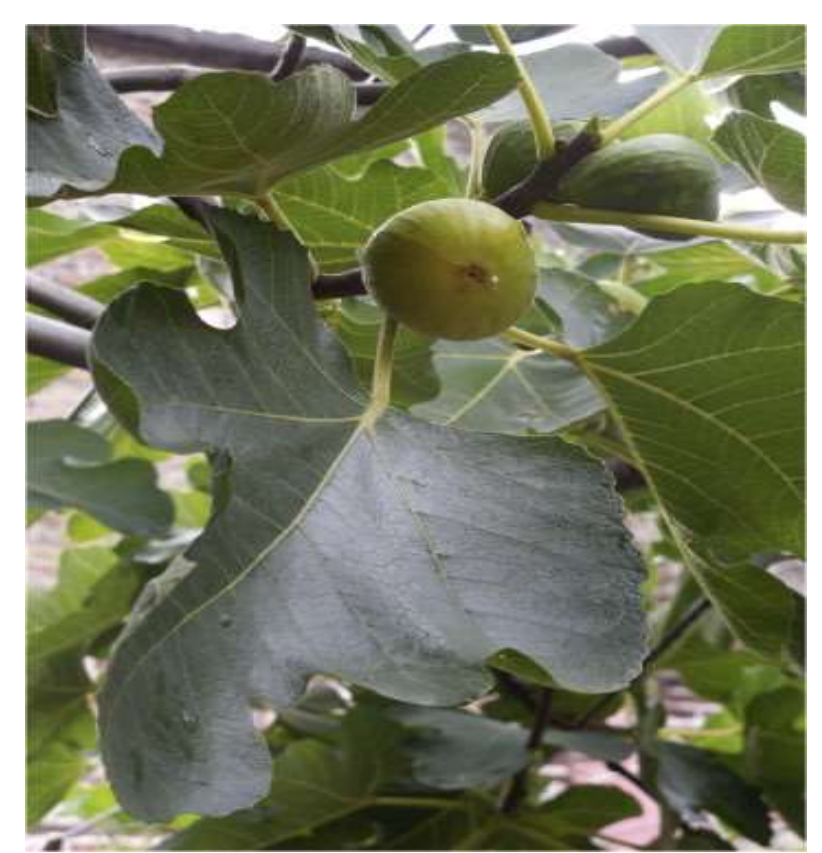

Şekil 1. Ocak ayında Rosario, Arjantin'de F. carica. (Fotoğraf: N. Ruiz Mostacero).

\subsection{Metot}

Araştırma materyali olan incir yaprakları, Ağustos ve Eylül (2019) aylarında bir haftalık periyotlar şeklinde toplanan yapraklar 7 gün boyunca $23 \pm 2^{\circ} \mathrm{C}^{\prime}$ de gölgede kurutulmuştur (Şekil 2). Daha önce yapılan çalışmalarda incir yaprakları, gölgede 5 gün boyunca $20 \pm 2^{\circ} \mathrm{C}^{\prime}$ de ve karanlık odada 2 hafta kurutulduğu belirtilmiştir [3,13]. Kuruyan yapraklar, mekanik bir öğütücü ile iri taneli toz çay haline getirildi (Şekil 3). Çalışmada, bitkisel çayların tarifine, sınıflandırma ve özelliklerine, numune alma, muayene ve deneyleri ile piyasaya arz şekline dair konuları içeren TS 12933 (ICS 67.140.10) numaralı Türk Standartları Enstitüsünün Standardında belirtilen analiz parametreleri tespit edilmiştir.

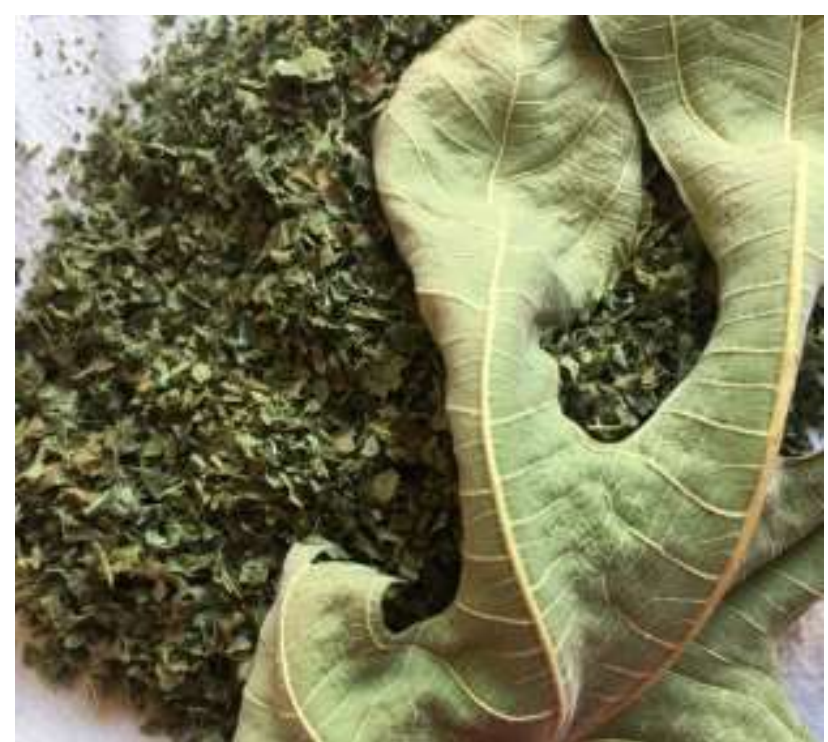

Şekil 2. 7 gün boyunca $23 \pm 2^{\circ} \mathrm{C}^{\prime}$ de gölgede kurutulan incir yaprakları 


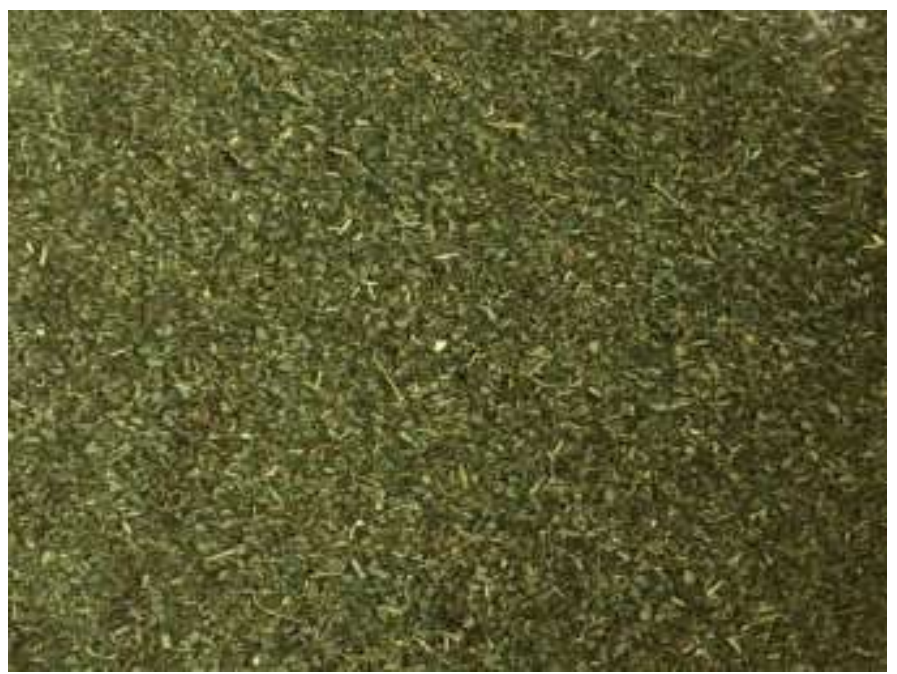

Şekil 3. Kurutulmuş ve öğütülmüş incir ağacı yaprakları

\subsubsection{Kuru madde tayini}

Kuru madde tayini, TS 1562 'ye göre yapılmıștır. Numune çay, 0,5 mm gözenekli elekten, tamamıyla geçecek şekilde öğütülmüştür. Darası alınmış temiz bir tartı kabı (porselen kapsül) içinde hassas terazide 5 gram çay numunesi tartılmıştır. Tartımı yapılan porselen kapsül içerisindeki çaylar etüvde $103 \pm 2^{\circ} \mathrm{C}^{\prime}$ de 6 saat bekletilmiştir. Kurutma işleminden sonra etüvden çıkarılan porselen kapsül desikatöre konularak bir müddet soğuması beklenmiştir. Daha sonra kapsül hassas terazide tartılmış ve tekrar etüvde 1 saat bekletildikten sonra desikatörde soğutulduktan sonra tartılmıştır.

Kuru madde miktarı $(\% \mathrm{~m} / \mathrm{m})=$ Kurutulmuş deney numunesi $(\mathrm{g}) \times(100 /$ deney numunesi $(\mathrm{g}))$ Belirtilen formül ile kuru madde miktarı hesaplanmıştır.

\subsubsection{Toplam kül tayini}

Toplam kül tayini TS 1564 'e göre yapılmıştır. Rutubeti önceden tespit edilmiş olan ögütülmüş çay numunesinden 3 gram tartılmış ve darası alınmış krozeye koyulmuştur. Kroze firında $525^{\circ} \mathrm{C}$ 'de yakılmıştır. 2 saat sonra kroze firından çıkartılarak soğutulmuştur. Yakma işlemi sona erince desikatöre konularak soğutulmuş ve tartılmıştır.

Toplam kül miktarı $(\% \mathrm{~m} / \mathrm{m})=(100 \times$ Külün ağırlığ $(\mathrm{g})) /$ kuru madde $(\mathrm{g})$ Belirtilen formül ile toplam kül miktarı hesaplanmıştır.

\subsubsection{Asitte çözünmeyen kül tayini}

Asitte çözünmeyen kül tayini, TS 1128 ISO 763'e göre yapılmıştır. Porselen krozedeki deney numunesine $25 \mathrm{ml} \mathrm{HCl}$ çözeltisi ilave edilmiştir. Sıçramayı önlemek için kroze bir saat camı ile kapatılarak hafif alev üzerinde 10 dakika süre ile kaynatılmış ve soğumaya bırakılmıştır. Kroze içindekiler süzgeç kâğıdından süzülmüş ve sıcak damıtık su ile yıkanmıştır Yıkama işlemine kalıntı asitten arınıncaya kadar devam edilmiştir. Süzgeç kâğıdı içindekilerle birlikte porselen krozeye alınmıştır. Isıtıcı üzerinde bir süre ssıtılarak suyu uçurulmuştur. Kalınt $1525^{\circ} \mathrm{C}$ 'de firında 60 dakika süre ile yakılmıştır. Daha sonra kroze desikatörde soğutularak, hassas terazide tartılmıştır.

Asitte çözünmeyen kül miktarı $(\% \mathrm{~m} / \mathrm{m})=\mathrm{m}_{3} \times\left(100 / \mathrm{m}_{0}\right) \times(100 / \mathrm{K})$

$\mathrm{m}_{0}=$ Toplam kül tayininde kullanılan ögütülmüş numuneden alınan deney numunesi ağırlığ $(\mathrm{gram})$

$\mathrm{m}_{3}=$ Asitte çözünmeyen külün ağırlığı (gram)

$\mathrm{K}=$ Ögütülmüş numunenin ağırlığa göre yüzde kuru madde miktarı

Belirtilen formül ile asitte çözünmeyen kül miktarı hesaplanmıştır.

\subsubsection{Aflatoksin tayini}

Aflatoksin tayini, EN 12955 'e göre yapılmıştır. 


\subsubsection{Mezofilik aerobik bakteri tayini}

Mezofilik aerobik bakteri tayini, TS 7703 ISO 4833'e göre yapılmıştır.

\subsubsection{Koliform bakteri tayini}

Koliform bakteri tayini, TS 7725 ISO 4831'e göre yapılmıştır.

\subsubsection{Escherichia coli tayini}

Escherichia coli tayini, TS 6063 ISO 7251'e göre yapılmıştır.

\subsubsection{Salmonella spp. tayini}

Salmonella spp. tayini, TS EN 12824'e göre yapılmıştır.

\subsubsection{Küf tayini}

Küf tayini, TS 6580’e göre yapılmıştır.

\subsubsection{Boya maddesi tayini}

Ögütülerek toz haline getirilmiş deney numunesinden yaklaşık $10 \mathrm{~g}$ kadar alınarak $50 \mathrm{~mL}$ damıtık su ilâve edilmiş 1-2 dakika kaynatılmıştır. Süzgeç kâğıdından süzülen süzüntü, içine 2-3 cm boyunda yün ipi atılan $1000 \mathrm{~mL}$ 'lik bir behere alınmıştır. Üzerine $1 \mathrm{~mL} \% 10$ 'luk $\mathrm{KHSO}_{4}$ ilâve edilerek su banyosunda 1 saat bekletilmiştir. Bir saat sonra boyayı emen yün ipi önce musluk suyu ile sonra damıtık su ile iyice yıkandıktan sonra başka bir $100 \mathrm{~mL}$ 'lik temiz behere alınmıştır. Beherdeki renkli çözelti $1 \mathrm{~mL}$ kalıncaya kadar buharlaştırılmıştır. Bu çözelti kromotografide kullanılacak çözeltidir. Kromatografi kâğıdı üzerinde tespit edilen boya numunelerinin $\mathrm{Rf}$ değerleri standart örneklerin $\mathrm{Rf}$ değerleri ile karşılaştırılarak boya maddeleri tanımlanmıştır.

\section{Bulgular ve Tartışma}

Çalışma sonucunda elde edilen verilen Tablo 1'de belirtilmiştir.

Tablo 1. İncir yaprak çayının analiz sonuçları

\begin{tabular}{|c|c|c|c|c|}
\hline \multicolumn{5}{|c|}{ Kimyasal Özellikler } \\
\hline & Sonuçlar & $\begin{array}{c}\text { Ölçüüm } \\
\text { Belirsizliği }\end{array}$ & Geri Kazanım & Referans Değer \\
\hline Kuru madde, $\%,(\mathrm{~m} / \mathrm{m})$ & 90,6 & $\pm 0,9$ & $\% 97$ & $>90$ \\
\hline Toplam kül, $\%,(\mathrm{~m} / \mathrm{m})$ & 14,19 & $\pm 0,5$ & $\% 101$ & $<9$ \\
\hline $\begin{array}{l}\% 10 \text { 'luk hidroklorik asitte } \\
\text { çözünmeyen kül, \%, (m/m) } \\
\text { Aflatoksinler }\end{array}$ & 4,36 & $\pm 0,3$ & $\% 97$ & $<2$ \\
\hline $\mathrm{B} 1, \mu \mathrm{g} / \mathrm{kg}$ & Tespit edilmedi & $\pm 0,05$ & $\% 101$ & $<2$ \\
\hline $\mathrm{B} 1+\mathrm{B} 2+\mathrm{G} 1+\mathrm{G} 2, \mu \mathrm{g} / \mathrm{kg}$ & Tespit edilmedi & $\pm 0,05$ & $\% 102$ & $<4$ \\
\hline Boya maddesi & Tespit edilmedi & $\pm 0,1$ & $\% 98$ & Bulunmamalı \\
\hline \multicolumn{5}{|c|}{ Mikrobiyolojik Özellikler } \\
\hline & Sonuçlar & $\begin{array}{c}\text { Ölçüüm } \\
\text { Belirsizliği }\end{array}$ & Geri Kazanım & Referans Değer \\
\hline Aerobik mezofilik bakteri (kob/g) & $8,2 \times 10^{2}$ & $\pm \% 8$ & $\% 103$ & $\operatorname{Max} 1,0 \times 10^{5}$ \\
\hline Koliform (kob/g) & $<10$ & $\pm \% 10$ & $\% 98$ & 95 \\
\hline Escherichia coli (E. Coli) (kob/g) & $<10$ & $\pm \% 10$ & $\% 99$ & 9 \\
\hline Salmonella spp. (kob/g) & Tespit edilmedi & $\pm \% 7$ & $\% 101$ & $\begin{array}{c}25 \text { gramda } \\
\text { bulunmayacak }\end{array}$ \\
\hline Küf (kob/g) & $2 \times 10^{2}$ & $\pm \% 8$ & $\% 97$ & $1,0 \times 10^{4}$ \\
\hline
\end{tabular}


TS 12933 Bitkisel Çaylar Standardına göre bitki çaylarında; toplam kuru madde miktarı en az $\% 90$, toplam kül miktarı en çok \%9, Aflatoksin B1 en fazla $2 \mu \mathrm{g} / \mathrm{kg}$, toplam aflatoksin miktarı en çok 4 $\mu \mathrm{g} / \mathrm{kg}$ olmalıdır. Mikrobiyolojik özelliklerine göre belirlenen referans değerleri ise, aerobik mezofilik bakteri (kob/g) en fazla 1,0 x 10 $0^{5}$, koliform (kob/g) en fazla 95, E. coli $(\mathrm{kob} / \mathrm{g})$ en fazla 9, Salmonella spp. (kob/g) 25 g'da bulunmamalı ve Küf (kob/g) en çok 1,0 x $10^{4}$ olacak şeklinde tanımlanmıştır. İncir yapraklarından çay elde edilmesi sonucu bu şekilde değerlendirme yapılan çalışmalar mevcut olmadığından, çalışmamızın sonuçlarında karşılaştırma yapılamamıştır. Fakat elde edilen sonuçların TS 12933 Bitkisel Çaylar Standardına uygunluğu karşılaştırılmıştır (Tablo 1). Üretilen incir ağacı yaprakları çayı, kimyasal olarak incelendiğinde toplam kuru madde, toplam kül, asitte çözünmeyen kül, tayinlerinin analiz sonuçları sırasıyla \%90.6, \%14.19, \%4.36 olarak belirlendi. Boyar madde ise tespit edilmedi. Toplam kül ve hidroklorik asitte çözünmeyen kül tayini dışında tüm sonuçlar TS 12933 Bitkisel Çaylar Standardına uygun bulundu. Toplam kül ve hidroklorik asitte çözünmeyen kül tayin sonuçları, standart referans değerlerinin üzerinde saptandı. TS 12933 standardında toplam kül miktarı en fazla $\% 9$, hidroklorik asitte çözünmeyen kül miktarı ise en fazla $\% 2$ istenmektedir. Türkiye'de sinameki olarak satılan bitki çayları üzerine yapılan bir araştırmada; çok daha yüksek kül ve asitte çözünmeyen kül miktarları elde edilmiştir. Toplam kül ihtivaları \%7.74 ve \%20.01 arasında, asitte çözünmeyen kül miktarları ise \%7.22 ile \%9.47 arasında değiştiği belirtilmiştir [19]. Ege bölgesinde yapılan bir çalışmada, rezene bitkisinin kül içeriği \%15.33 olarak saptanmıştır [20]. Çay olarak tüketilebilecek bitkilerde, bitkinin yetiştirildiği toprağın mineral madde içeriği ile bitkilerde kullanılan gübrelemenin, toplam kül miktarına etkide bulunduğu yapılan çalışmalarda bildirilmiştir [21]. Ayrıca, çay bitkilerinde bulunan bu mineral maddeler, suda çözünmeyen ve suda çözünen olmak üzere iki gruba ayrılmaktadır. Suda çözünen küldeki mineral maddeler çayların dem kısmına ve insan vücuduna kolaylıkla geçebilmektedir. Çayın kül içeriği, zirai mücadele ilaçlarının kullanım oranına, ham maddenin işlenme şartlarına bağlı olarak da değişebilmektedir. Dolayısıyla, çaylarda yüksek kalite açısından, düşük kül miktarı istenmektedir [22]. Yaptığımız çalışmada, toplam kül ve hidroklorik asitte çözünmeyen kül miktarlarının, standart referans değerinin üzerinde bulunmasının; ağaçların yetiştiği toprağın mineral madde içeriğinden kaynaklanabileceği düşünülmektedir.

Kuru incirde yaşanan aflatoksin problemi yıllardır bilinen ve üzerine birçok araştırma yapılan bir konudur. Bazen incirde mikotoksin oluşumu ağaçta başlayabilir ve bunu takiben hasat ve depolama süresince devam edebilir [23]. Bu yüzden incir ağacı yaprakları aflatoksin içeriğinin de tayin edilmesi önemli bir konudur. Çalı̧̧mamızda, kurutulan ve çay haline getirilen incir ağacı yapraklarında Aflatoksin B1 ve diğer aflatoksinler tespit edilmedi. Üretilen incir ağacı yaprakları, mikrobiyolojik olarak incelendiğinde; küf miktarı $2 \times 10^{2}$ (kob/g), E. coli miktarı ve Koliform miktarı (kob/g) <10, Aerobik mezofilik bakteri (kob/g) miktarı 8,2 x $10^{2}$ olarak belirlendi. Salmonella spp. (kob/g) ise tespit edilmedi. İncir yapraklarında Türk Standartları Enstitüsünün bitki çaylarına yönelik belirlediği mikrobiyolojik parametrelerin referans değerlerine göre analiz sonuçları sınır değerleri arasında tespit edilmiştir.

\section{Sonuç ve Öneriler}

Tıp alanında uzman birçok bilim insanı son yıllarda $F$. carica 'ya yönelmiştir. Çünkü kimyası, besin değeri, farmokolojik kullanım alanları araştırılan $F$. carica'nın gelecekte umut verici biyo ürünlerden biri olduğu belirtilebilir. Bu konuda pek çok çalışma yürütülse de, incir ağacının kimyasal bileşimi üzerine yapılan araştırmalar devam etmektedir. Bu araştırmalar incelendiğinde, $F$. carica yapraklarının fenolik ve flavanoid bileşiklerce zengin olması, antioksidan ve antimikrobiyal maddeler içermesi nedeniyle sadece meyvesinin değil bir bütün olarak incirin faydalı model üretimlerinde iyi bir kaynak olduğu düşünülmektedir. Günümüzde sudan sonra en çok tüketilen içecekler çay ve bitki çaylarıdır. Sağlığa faydaları nedeniyle, son yıllarda bitki çaylarına artan bir ilgi söz konusudur. Çalışmamızda yapılan analiz sonuçlarına göre incir yaprak çayının, ulusal bitki çayı standardına göre değerlendirilmesi ilk kez incelenmiştir. Araştırmam sonucunda oluşan kanaat, incirin en çok üretildiği Aydın ilinde özellikle de Germencik ilçesinde, gelirinin önemli bir kısmını incirden elde eden tarımsal işletme sahiplerinin incir ağacının meyvesi dışındaki kısımlarından katma değerli ürünlerden faydalanabilmeleri ve bu ürünlerin gelişmiş kullanımlarına yönelik olarak incir ağacı yaprakları bitki çayı üretiminde değerlendirilebilir. 


\section{Teşekkür}

Bu çalışma Aydın Adnan Menderes Üniversitesi Bilimsel Araştırma Projeleri Birimi tarafından GYMYO-19001 numaralı proje ile desteklenmiştir.

\section{Yazarların Katkısı}

Mustafa SÜRMEN, incir yapraklarının temini ve kalitesi yönünde çalışmaları, Erdinç VURAL ürün geliştirme için gerekli makine ekipman donanımları ve optimizasyon çalışmaları, Nergiz YÜKSEL ürünün üretim aşamalarını belirleme ve ilgili standartlara uygunluğuna yönelik analizleri planlama çalışmaları yaparak araştırmaya katkı sunmuştur.

\section{Çıkar Çatışması Beyanı}

Yazarlar arasında herhangi bir çıkar çatışması bulunmamaktadır.

\section{Araştırma ve Yayın Etiği Beyanı}

Yapılan çalışmada araştırma ve yayın etiğine uyulmuştur.

\section{Kaynaklar}

[1] Barolo M.I., Mostacero N.R., López SN. 2014. Ficus carica L. (Moraceae): An Ancient Source of Food and Health. Food Chemistry, 164: 119-127.

[2] Lightbourn A.V., Soliman K.F.A., Thomas R.D. 2019. Crude Edible Fig (Ficus carica) Leaf Extract Prevents Diethylstilbestrol (DES)-Induced DNA Strand Breaks in Single-Cell Gel Electrophoresis (SCGE)/Comet Assay: Literature Review and Pilot Study. Journal of Bioequivalence \& Bioavailability, 11 (1): 19-28.

[3] Nadeem M., Zeb A. 2018. Impact of Maturity on Pphenolic Ccomposition and Antioxidant Activity of Medicinally Important Leaves of Ficus carica L. Physiology and Molecular Biology of Plants, 24 (5): 881-887.

[4] Food and Agriculture Organization of The United Nations (FAO). 2019. İstatistikler. http://www.fao.org/statistics/ databases/en/.( Erişim tarihi: 10.11.2019).

[5] Türkiye İstatistik Kurumu (TUIK). 2019. Konularına Göre İstatistikler. https://web.tuik.gov.tr/tr/classification-categories/. (Erişim tarihi: 08.11.2019).

[6] Cavero R.Y., Akerreta S., Calvo M.I. 2013. Medicinal Plantsused for Dermatological Affectionsin Navarraand, Their Pharmacological Validation. Journal of Ethnopharmacology, 149: 533-542.

[7] Silva Rody H.V., Gontijo D.C., Miranda Coelho V.P., Ventrella M.C., Pádua R.M., Fietto L.G., Viana Leite J.P. 2018. Mutagenic Activity and Chemical Composition of Phenolic-rich Extracts of Leaves from Two Species of Ficus Medicinal Plants. Journal of Toxicology and Environmental Health, Part A, 81 (17): 861-872.

[8] Lianju W., Weibin J., Kai M., Zhifeng L., Yelin W. 2003. The Production and Research of Fig (Ficus carica L.) in China. ISHS Acta Horticulturae 605: II International Symposium on Fig, 28 Nisan, İspanya, 191-198.

[9] Oliveira A.P., Silva L.R., Pinho P.G., Gil-Izquierdo A., Valentão P., Silva B.M. 2010. .Volatile Profiling of Ficus carica Varieties by HS-SPME and GC-IT-MS. Food Chemistry, 123: 548-557.

[10] Saeed M.A., Sabir A.W. 2002. Irritant Potential of Triterpenoids from Ficus carica Leaves. Fitoterapia, 73: 417-420.

[11] Brown P.H. 1994. Seasonal Variations in Fig (Ficus carica L.) Leaf Nutrient Concentrations. Hortscience, 29 (8): 871-873.

[12] Mahmoudi S., Khali M., Benkhaled A., Benamirouche K., Baiti I. 2016. Phenolic and Flavonoid Contents, Antioxidant and Antimicrobial Activities of Leaf Extracts from Ten Algerian Ficus carica L. Varieties. Asian Pacific Journal of Tropical Biomedicine, 6 (3): 239-245 
[13] Rostam M.A., Salleh S., Harun A.F., Ali A.N. 2018. The Antimicrobial Activities of Fig (Ficus carica L.) Leaves Extract Against Staphylococcus aureus and Escherechia coli. International Journal of Allied Health Sciences, 2 (1): 273-285.

[14] Jeong M.R., Hye-Young Kim H.Y., Cha J.D. 2009. Antimicrobial Activity of Methanol Extract from Ficus carica Leaves Against Oral Bacteria. Journal of Bacteriology and Virology, 39 (2): 97-102.

[15] Badgujar S.B., Patel V.V., Bandivdekar A.H., Mahajan T.T. 2014. Traditional Uses, Phytochemistry and Pharmacology of Ficus carica: A Review. Pharmaceutical Biology, 52 (11): 1487-1503.

[16] Mopuri R., Ganjayi M., Meriga B., Koorbanally N.A., Islam S. 2018. The Effects of Ficus carica on the Activity of Enzymes Related to Metabolic Syndrome. Journal of Food and Drug Analysis, 26: 201-210.

[17] Zhang Y., Wan Y., Huo B., Li B., Jin Y., Hu X. 2018. Extracts and Components of Ficus carica Leaves Suppress Survival, Cell Cycle, and Migration of Triple-negative Breast Cancer MDAMB-231 Cells. Onco Targets and Therapy, 11: 4377-4386.

[18] Pérez C., Domínguez E., Canal J.R., Campillo J.E., Torres M.D. 2000. Hypoglycaemic Activity of an Aqueous Extract from Ficus carica (Fig Tree) Leaves in Streptozotocin Diabetic Rats. Pharmaceutical Biology, 38 (3): 181-186.

[19] Deliorman Orhan D., Sayın E. 2016. Türkiye'de Sinameki Olarak Satılan Bitkiler Üzerinde Yapılan Kalite Kontrol Analizleri. Clinical and Experimental Health Sciences, 6 (3): 116-120.

[20] Kaya İ., İncekara N., Nemli Y. 2004. Ege Bölgesi'nde Sebze Olarak Tüketilen Yabani Kuşkonmaz, Sirken, Yabani Hindiba, Rezene, Gelincik, Çoban Değneği ve Ebegümecinin Bazı Kimyasal Analizleri. Yüzüncü Y1l Üniversitesi, Ziraat Fakültesi Tarım Bilimleri Dergisi, 14 (1): $1-6$.

[21] Turan M.A., Balcı M., Taşkın M.B., Kalcığlu3 Z., Soba M.R., Müezzinoğlu N., Kaya E.C., Özer P., Kabaoğlu A., Taban S. 2016. Doğu Karadeniz Bölgesi’nde Yetiştirilen Çay Bitkisi (Camellia sinensis L.) Yaşlı Yapraklarının Su Ekstrakt1, Toplam Kül, Toplam Polifenol, Kafein ve Ham Selüloz İçerikleri. Toprak Su Dergisi, 5 (2): 52-58.

[22] Safi T. 2018. Çay Atıklarından Yararlanarak Çay Özütü Miktarının Arttırılması. Yüksek Lisans Tezi, Recep Tayyip Erdoğan Üniversitesi, Fen Bilimleri Enstitüsü, Rize.

[23] Şen L., Nas S. 2010. Kuru İncir, Üzüm ve Kırmızıbiberlerde Mikotoksin Varlığı. Akademik Gıda, 8 (3): 24-32. 